\title{
Correction to: Physical Model of Tire-Road Contact Under Wet Conditions
}

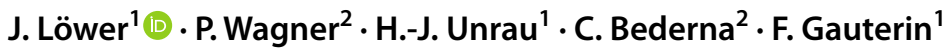

Published online: 16 May 2021

(c) The Author(s) 2021

\section{Correction to: Tribology Letters (2020) 68:25 https://doi.org/10.1007/s11249-019-1264-6}

The article "Physical Model of Tire-Road Contact Under Wet Conditions", written by "J. Löwer, P. Wagner, H.-J. Unrau, C. Bederna, F. Gauterin", was originally published Online First without Open Access. After publication in volume 68, issue 1, the author decided to opt for Open Choice and to make the article an Open Access publication. Therefore, the copyright of the article has been changed to $($ ) The Authors 2021 and the article is forthwith distributed under the terms of the Creative Commons Attribution 4.0 International License, which permits use, sharing, adaptation, distribution and reproduction in any medium or format, as long as you give appropriate credit to the original author(s) and the source, provide a link to the Creative Commons licence, and indicate if changes were made. The images or other third party material in this article are included in the article's Creative Commons licence, unless indicated otherwise in a credit line to the material. If material is not included in the article's Creative Commons licence and your intended use is not permitted by statutory regulation or exceeds the permitted use, you will need to obtain permission directly from the copyright holder. To view a copy of this licence, visit http://creativecommons.org/licenses/by/4.0.

The original article has been corrected.

The original article can be found online at https://doi.org/10.1007/ s11249-019-1264-6.

\section{J. Löwer}

jan.loewer@kit.edu

1 Institute of Vehicle System Technology, Karlsruhe Institute of Technology, Rintheimer Querallee 2, 76131 Karlsruhe, Germany

2 Continental Reifen Deutschland GmbH, Hannover, Germany
Publisher's Note Springer Nature remains neutral with regard to jurisdictional claims in published maps and institutional affiliations. 